\title{
Increase of the municipal land and property complex attractiveness on the basis of the development of cities infrastructure in Russia
}

\author{
Yelena Stein $^{1, *}$, Natalia Taskaeva ${ }^{1}$, and Tatiana Slepkova $^{2}$ \\ ${ }^{1}$ Moscow State University of Civil Engineering, Yaroslavskoe shosse, 26, Moscow, 129337, Russia \\ ${ }^{2}$ College of Modern Technologies named after the Hero of the Soviet Union M. F. Panov, Khibinsky \\ proezd, 10, Moscow, 129337, Russia
}

\begin{abstract}
The article presents the hierarchy levels of the land and property complexes of the Russian Federation and their basic elements. Characteristics of the land and property complex of the municipal entity as the object of management were studied. The head of the municipal administration is considered as the subject of the land and property complex management of the municipal level. The evaluation criteria of his/her performance results in order to determine the attractiveness of cities for living are presented. The article presents a methodological approach to the assessment of the attractiveness of the urban environment for living, based on which significant quality factors of urban living environment and threshold of cities attractiveness were determined. The threshold of cities attractiveness shall be used as the main criterion for enhancement of mayors and heads of administrations of Russian cities performance and the urban development programs preparation.
\end{abstract}

\section{Introduction}

Creating a comfortable living environment is one of the main tasks of town-planning and housing policy. Comfortable environment promotes satisfaction of the housing needs of the population and ensures a high quality of life in general.

The effectiveness of such policy is significantly increased, if the relevant territories under review are considered as separate parts, with regard for the development of social, transport and engineering infrastructure, as well as development prospects of the region and cities under consideration.

Creating a comfortable living environment for population together with the more efficient use of land resources as a part of the land and property complex shall be considered as one of the ways to accelerate the economic development [1]. Taking into account that the land and property complex is, on the one hand, a natural resource, and on the other hand, a factor of the reproduction process, it should be considered as a base

\footnotetext{
*Corresponding author: natalia.taskaeva@yandex.ru
} 
element of social and land and property relations. Currently, there is no single sound system of indicators for the effectiveness analysis of the land and property complex operation at the different administrative and territorial levels of the Russian Federation. The choice of the land and property complex utilization efficiency indicators is ambiguous. The use of the valid system of indicators for the analysis of management efficiency of the land and property complex is complicated due to the lack of sufficient technical and economic information about the object of the analysis. Evaluation of the land and property complex management efficiency while addressing the different national economy targets in most cases is aggravated by the difficulty in determining a material contribution of the output in the final product of a particular region.

During the study of attractiveness factors of the urban environment for living a need for successive solutions of the following tasks arises:

- Considering the characteristics of the land and property complex of the municipal entity as the object of management,

- Formation of the main development directions of the territorial infrastructure of municipal entities,

- Determining the infrastructure development mechanism on the basis of the publicprivate and municipal-private partnerships.

\section{Methodology and Methods}

The land and property complex is an artificially created complex in specific spatialtemporal conditions, which operates due to the human activity to meet different needs and develop territories, but with social, economic orientation [2].

The following types of land and property complexes are determined within the state:

- Land and property complex of the constituent entity of the Russian Federation or municipal entity, as a land resources pool, real estate units and other related natural and human resources in the constituent entity property of the Russian Federation (or municipal entity),

- Land and property complex of the local level, as a specific object of property rights, overall land lots and located on them other real estate units of the specific functional purpose, belonging to a particular legal entity (or natural person).

- The Federal State Statistics Service takes into account such land and property complexes as:

- Municipal district (it includes one or several settlements within the same territory under local self-government addressing the issues of local significance directly by citizens or local government authorities, and they can only exercise certain public powers determined by Federal Laws and Laws of the constituent entities of the Russian Federation),

- Inter-settlement territory (this includes the territory outside the boundaries of settlements),

- Urban district (urban settlement not included in the municipal district where local government authorities exercise powers of local significance, as well as certain public powers determined by Federal Laws and Laws of the constituent entities of the Russian Federation),

- Urban settlement (town or village and surrounding areas, or rural communities which are part of the urban settlement, and not rural settlements, where the local government is exercised directly by citizens or local government authorities),

- Rural settlement (combines several rural communities, such as villages, cossack villages, hamlets, kishlaks, mountain villages and others that share a common territory 
and where the local government is exercised directly by citizens or local government authorities),

- Intracity area (intracity municipal unit of the federal city conceived as a part of the federal city territory, where the local government is exercised directly by citizens or local government authorities) [3].

In Table 1 shows presents hierarchical levels of land-property complexes and their main elements.

Table 1. Hierarchy levels of the land and property complexes and their basic elements.

\begin{tabular}{|c|c|c|c|}
\hline $\begin{array}{l}\text { Level of } \\
\text { management } \\
\text { hierarchy }\end{array}$ & $\begin{array}{l}\text { Aspects of } \\
\text { ownership of } \\
\text { controlled } \\
\text { elements of land } \\
\text { and property } \\
\text { complexes }\end{array}$ & $\begin{array}{c}\text { Aspects of } \\
\text { ownership of } \\
\text { regulating elements } \\
\text { of land and property } \\
\text { complexes }\end{array}$ & $\begin{array}{c}\text { Elements of } \\
\text { land and property } \\
\text { complexes }\end{array}$ \\
\hline $\begin{array}{l}\text { Russian } \\
\text { Federation }\end{array}$ & $\begin{array}{l}\text { State federal } \\
\text { property }\end{array}$ & $\begin{array}{c}\text { State sub-federal, } \\
\text { municipal, private } \\
\text { and other types of } \\
\text { property }\end{array}$ & $\begin{array}{l}\text { Vacant federal lands and land lots } \\
\text { encumbered by natural resources, } \\
\text { land and property complexes of } \\
\text { federal settlements and economic } \\
\text { entities, land and property } \\
\text { complexes of constituent entities } \\
\text { of the Federation }\end{array}$ \\
\hline $\begin{array}{l}\text { Constituent } \\
\text { entity of the } \\
\text { Federation }\end{array}$ & $\begin{array}{l}\text { State sub-federal } \\
\text { property }\end{array}$ & $\begin{array}{l}\text { State federal property } \\
\text { under the jurisdiction } \\
\text { of the constituent } \\
\text { entity of the } \\
\text { Federation, } \\
\text { municipal, private } \\
\text { and other types of } \\
\text { property within its } \\
\text { territory }\end{array}$ & $\begin{array}{l}\text { Vacant sub-federal lands and land } \\
\text { lots encumbered by natural } \\
\text { resources, land and property } \\
\text { complexes of settlements and } \\
\text { economic entities, municipalities } \\
\text { located in the territory of this } \\
\text { constituent entity of the } \\
\text { Federation }\end{array}$ \\
\hline Municipality & $\begin{array}{l}\text { Municipal } \\
\text { property }\end{array}$ & $\begin{array}{l}\text { State sub-federal } \\
\text { property under the } \\
\text { jurisdiction of the } \\
\text { municipality, private, } \\
\text { mixed and other types } \\
\text { of property within its } \\
\text { territory }\end{array}$ & $\begin{array}{l}\text { Land and property complexes of } \\
\text { municipal settlements and } \\
\text { economic entities in the territory } \\
\text { of the municipality }\end{array}$ \\
\hline $\begin{array}{l}\text { Economic } \\
\text { entity }\end{array}$ & $\begin{array}{l}\text { State, municipal, } \\
\text { private, mixed and } \\
\text { other types of } \\
\text { property }\end{array}$ & $\begin{array}{l}\text { State, municipal, } \\
\text { private and other } \\
\text { types of property } \\
\text { used in the economic } \\
\text { entity activity }\end{array}$ & $\begin{array}{l}\text { Land lots, items of immovable } \\
\text { property, movable assets related } \\
\text { to fixed assets, movable property } \\
\text { related to working capital, } \\
\text { movable property related to } \\
\text { intangible assets }\end{array}$ \\
\hline
\end{tabular}

The land and property complex management is carried out within the aggregate spaces that include social, political, legal, economic, cultural, historical, natural and climatic and ecological spaces. The problem of its functioning is complex and multidimensional [4,5]. The following factors are identified among the major factors affecting the development of land and property complex: transformation of administrative bodies and economic management mechanisms, development of real estate markets and investments, activities of diverse private investment, legal and educational structures.

It seems that in modern market conditions the definition of land and property complex shall be adjusted and considered primarily as:

- An application object of human intellectual, financial, innovative capacity, 
- A place to meet human needs for recreation, entertainment,

- A place of non-profit activities.

This approach is supported by the fact that the population with the intention to settle on a particular territory, first of all, is looking for a place where it will be able to realize all the above needs. The population should have a choice and a chance to compare between alternatives, competitive advantages of different territories. In this case, attractiveness of the urban environment for living shall be considered as the main purpose of territories development, and diversity of types of items of immovable property will be focused on ensuring the comfort of the population, creating a friendly environment for its physical and psychological health [6].

The issue related to the management of conditions creation for the managerial decisions, their adoption and further implementation is becoming increasingly important [7]. Managerial decision in this case is an alternative choice from the totality of managerial decisions that the manager shall make it by himself/herself. It will allow him/her to fulfill his/her duties regulated by the position in accordance with the competence that contributes to the achievement of organization's goals. The decision taken shall be effective to ensure the performance of administrative functions. Managerial decision making can be presented as a process consisting of a series of individual acts and procedures including but not limited to the so-called strong-willed factor that can be considered as a factor determining the process of development and decision making. Studies have shown that at this stage of development of land and property relations the strong-willed factor plays a significant role [8]. The strong-willed factor function is to ensure the selection of one variant from the totality of alternative managerial decisions.

The decision making process forms the basis for the management. The responsibility for making important managerial decisions places a heavy moral burden on managers and is particularly manifested at the highest management levels. When considering a particular base at the heart of the decision to be taken, the intuitive decisions, decisions based on judgments and rational decisions shall be distinguished. However, all managerial decisions must be based on sound objective decisions achieved through the use of a scientific approach to the decision-making process, relying on models and quantitative methods of managerial decision-making. Rational decisions are based on the methods of economic analysis, justification and optimization. The government bodies must constantly monitor the condition of the housing stock, communications and services provided [9]. Today, there is an urgent need to move from intuitive decisions of even very talented managers to rational decisions based on objective calculations.

\section{Results}

The choice of management method shall correspond to the land and property complex level. Therefore, it is necessary to synchronize objectives and levers of influence to ensure the attractiveness of urban living environment. In 2014, the general rating of the best mayors of Russian cities was created by the Russian Union of Engineers. Rating replaced the General ranking of attractiveness of Russian cities, the Russian Union of Engineers thus recognized that the effective development of the territory depends on the management level and rational decision-making by the manager. The purpose of rating is to provide an objective comprehensive assessment of "effectiveness" of the Russian cities mayors on the basis of indicators that will enable to determine the development levels of all aspects of living conditions for the population, urban economy and urban environment. This rating is the method of analysis and comparison of the combination of factors that affect the quality of urban living environment and is a key element in the mayors activity. It showed that the level of mayors interest in improving the economic potential and urban environment 
quality, development of the effective urban management mechanisms is high and tend to grow.

Management at the level of municipal district, as well as the city or region is a great responsibility and the incumbent of the head of territory shall be an expert versed in the various fields of activities on the territory entrusted to him/her. Adoption of the managerial decision shall be the result of in-depth analysis of factors and evaluation of manager action results.

The English word "rating" is derived from the verb "to rate" - "to evaluate, make estimate". In Russian the word "rating" has two basic meanings:

1. a measure of the popularity of someone or something based on the audience likes (TV program rating), public opinion surveys (the President's rating) or expert opinions, expressed as a percentage;

2. the list of leaders on a particular indicator among people, TVs, parties, cities, softwares, mobile phones and the like, which are usually drawn up by the results of expert studies or surveys of audience with the parameter by which the comparison of leaders is made and the winners are designated.

The reference literature provides an explicit interpretation of this concept. Most of them can be systematized as follows:

- Rating as an assessment determined by referring to any class or rank, or category,

- Rating as a numerical expression of a particular qualitative concept,

- Rating as a positioning of the object to be evaluated in the group of similar objects by assigning it a number on the basis of quantitative and qualitative indicators,

- Rating as the definition of public opinion with respect to the object under study.

Under actual conditions the mayors of Russian cities are starting to realize that the socio-economic and economic-environmental condition of the territory depends on the mayor policy and his/her decisions. Their activities shall be aimed at creating conditions for strengthening of competitive advantages of the city, maintaining the ever-growing living standards of population of the city due to the growth of development indicators of social, engineering and transport infrastructure $[10,11]$. The ability of mayor to form the necessary information base, process it analytically and take the right managerial decision determines the effectiveness of the land and property complex development. Of course, the possibility of making the right managerial decisions by means of the intuitive targets selection and ways of dealing with the problem has not been ruled out. But according to the experience, rational managerial decisions based on calculations better define the basic parameters of the territory development and enable highlighting the major factors of the territory development and assess their impact, and hence improve the efficiency of the decisions to be taken.

In recent years, the ranking becomes an important area of assessment of economic activities at different management levels. This approach is relevant both in Russia and in the world community as a whole. Such indicators as talent, genius, authority and popularity are most commonly used in relation to the head of the municipal administration in the ranking system assessing the quality of his/her managerial decisions. These figures are presented in the quantitative variables.

Table 2 shows the most common ratings of the attractiveness of cities and methods of rating research.

Table 2. Modern rating researches of cities attractiveness.

\begin{tabular}{|l|l|}
\hline \multicolumn{1}{|c|}{ Rating name } & \multicolumn{1}{|c|}{ The organization conducting a research } \\
\hline $\begin{array}{l}\text { The integral rating of the largest cities of } \\
\text { Russia (TOP-100) according to data of } \\
2014\end{array}$ & Union of Architects of Russia \\
\hline
\end{tabular}




\begin{tabular}{|l|l|}
\hline $\begin{array}{l}\text { Rating for Russian Cities in 2015. The best } \\
\text { cities of Russia for you }\end{array}$ & "Nesiditsa" site research \\
\hline $\begin{array}{l}\text { Quality of living ranking for Russian cities } \\
\text { in } 2015 \text { (assessment of the quality of life in } \\
\text { Russian cities) }\end{array}$ & $\begin{array}{l}\text { Financial University under the Government of the } \\
\text { Russian Federation } \\
\text { Department of Sociology }\end{array}$ \\
\hline $\begin{array}{l}\text { Living standards ranking for Russian cities } \\
\text { in 2014-2015 }\end{array}$ & RatingS site research \\
\hline 250 largest industrial centers of Russia & Institute of Spatial Planning "Urbanica" \\
\hline $\begin{array}{l}\text { Quality of living ranking for Russian cities } \\
\text { (Top-20) - 2010 }\end{array}$ & Institute of Spatial Planning "Urbanica" \\
\hline 30 best Russian cities for business - 2010 & Institute of Spatial Planning "Urbanica" \\
\hline $\begin{array}{l}\text { The most attractive Russian cities for } \\
\text { business - 2010 }\end{array}$ & Institute of Spatial Planning "Urbanica" \\
\hline Global cities - 2011 & Institute of Spatial Planning "Urbanica" \\
\hline World's cities rating - 2011 & Institute of Spatial Planning "Urbanica" \\
\hline $\begin{array}{l}\text { Living standards ranking for Russian cities } \\
\text { in } 2015\end{array}$ & Rosgosstrakh Center for Strategic Studies \\
\hline Rating for the best Russian Cities in 2014 & Annual publication "Company secret" \\
\hline $\begin{array}{l}\text { Ranking of the best cities in the world for } \\
\text { living }\end{array}$ & Well-known analytical company \\
\hline $\begin{array}{l}\text { Russian governors rating for 2015: } \\
\text { Complete list }\end{array}$ & Civil Society Development Foundation \\
\hline $\begin{array}{l}\text { Top 10 cities in Russia for budget costs per } \\
\text { capita }\end{array}$ & Cycling activist and part-time blogger Ilya \\
\hline Top 10 most inhospitable cities in the world & Travel + Leasure magazine \\
\hline Top 10 fastest-growing cities of Russia & "RBC" research \\
\hline Top 10 most expensive cities in 2012 & Basetop site research \\
\hline $\begin{array}{l}\text { The most popular cities of Russia among } \\
\text { foreign tourists }\end{array}$ & hotels.com Internet resource research \\
\hline The best cities of Russia for business & "Forbes" research \\
\hline
\end{tabular}

The attractiveness of rating methods in the evaluation of mayors' activity can be explained by the general operating conditions of modern social systems and the possibility to standardize the results in order to achieve assessment goals, regardless of the venue.

Today, it is obvious that the development goals must be determined for the effective development of the land and property complex. They should be selected from the set of goals based on their hierarchy and economic sense (Figure 1).
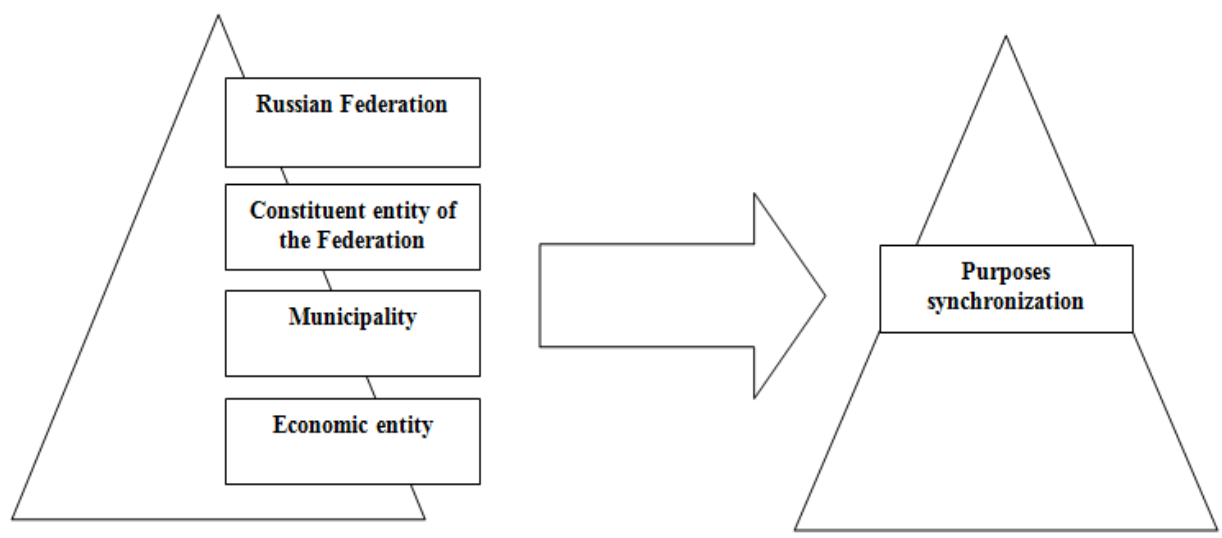

Fig 1. The land and property complex management levels hierarchy diagram. 
This approach gives the possibility to specifically dispose of all types of resources of the land and property complex and optimize the derived from their use effect in the development of land and property complex.

Determination of the integrated socio-economic level of development of the land and property complex includes three main positions: infrastructure development of the land and property complex, development master plan of the land and property complex and development of all main spheres of its life. The most significant impact factor on the urban living environment attractiveness level is the infrastructure sphere.

In foreign practice, the term "public works" is widely used, which includes a complete definition of infrastructure. In Russia, a comprehensive definition of infrastructure requires clarification, especially if this definition is related to the separate sectors, such as transport infrastructure, engineering infrastructure, including public utility, housing infrastructure, social infrastructure.

For instance, the development of transport infrastructure in Russia lags behind the vehicle fleet growth, but also dramatically slowed down in recent years. Investing in the road sector for 2013-2014 was decreased by $40 \%$. The maintenance of roads is reduced only to their repair, and as a result, the Russian roads conditions have deteriorated significantly. According to Rosstat and the Federal Road Agency data, the share of public roads that meet the regulatory requirements in the constituent entities of the Russian Federation is being constantly reduced (Figure 2).

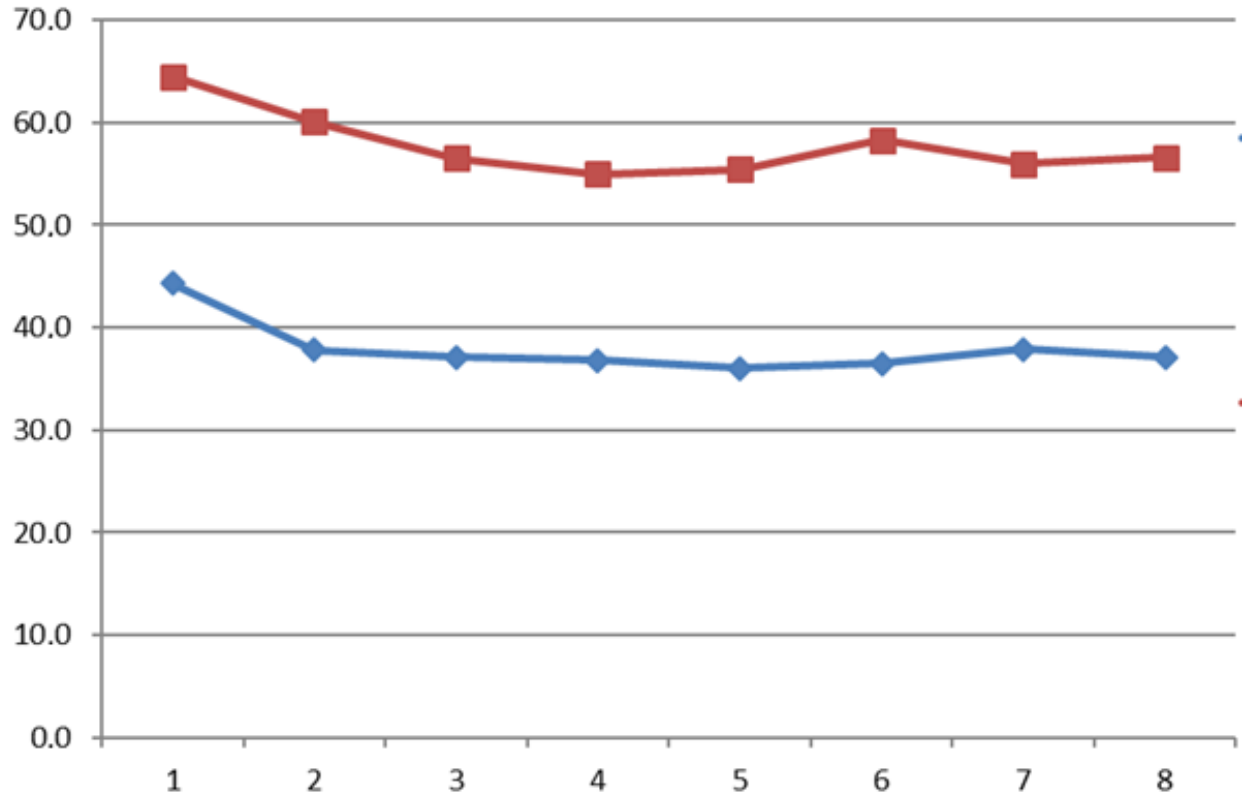

Fig. 2. The share of public roads that meet the regulatory requirements: regional and inter-municipal significance from $64.5 \%$ to $56.6 \%$, local significance from $44.3 \%$ to $37.3 \%$.

Thus, the share of inter-municipal and regional roads that meet requirements decreased from $44.3 \%$ in 2007 to $37.3 \%$ in 2014 , the share of local roads is decreased to $64.5 \%$ to $56.6 \%$, respectively. While abroad, the main direction of reforms in this industry has established, and in some countries, such as Japan and Switzerland already implemented the transition from costly repairs to the more economical maintenance, i.e. the whole complex of road works is focused on preventive actions. In this respect, it is interesting to note the recommendations of international organizations to impose tariffs for roads maintenance 
included in the price of motor fuel (which is technologically easier than the toll roads), and accumulated in the special trust fund, which would be managed by representatives of user organizations $[12,13]$.

Engineering infrastructure, unlike other infrastructures, together with the transport system has a range of facilities for the production of engineering products. This type of products includes the enterprises for the "enrichment" - natural and waste water treatment, heat and energy generation resources, waste removal and treatment enterprises. In modern engineering infrastructure and public utilities, according to Rospotrebnadzor, only $62.1 \%$ of Russia's population uses the safe water. In the sphere of water supply only $55.5 \%$ of the water supplied to the system is processed to the standard level, and only $45 \%$ of wastewater is processed to the standard level in the sphere of water disposal and wastewater treatment. Hot water supply shortages have $48 \%$ of the population, cold water supply shortages - $42 \%$ of the population, interruptions in electricity $-28 \%$ of the population.

Housing infrastructure, in contrast to housing and utilities sector and engineering infrastructure is usually not referred to the infrastructure. Surely, separate apartments and family homes represent a private good, but housing in general as housing fund, certainly is a part of infrastructure. Russia Housing Fund now stands at 3.3 bln sq. m. In recent years, the situation in the housing and utilities sector defined one of the most important state problems. According to VTsIOM, 58\% of respondents gave the first place to the challenges in the sphere of housing and utilities sector in 2012 and 53\% - in 2013. In 2014, they have moved these challenges to the second place that in general does not alleviate this problem.

A number of authors note that one of the characteristics of the land and property complex as the infrastructure network is that it can only be operated as a whole; the competition between its parts is technically impossible and makes no economic sense. In other words, economic and social specific of infrastructure requires its organization within the public sector of the economy, leading entity where regional and local administrations should remain in the future. Thus, the economic feasibility reasons dictate the management of land and property complex within the territorial framework of the settlement as an entire entity.

However, today the poor state of infrastructure becomes one of the main factors hampering economic growth. In the represented by the media "General rating of the attractiveness of urban living environment (habitat) according to the results of the cities activity in 2011", which includes 164 cities, the Russian Union of Engineers has developed and introduced a new assessment criterion for urban opportunities and urban management quality - this is a threshold of attractiveness, which enables to select the most attractive to populations and prospective investors from the general list of cities represented in the rating. The selection of criteria for the comparison of cities in the rating is strictly balanced, based on full coverage of municipal services performance and analysis of the urban living conditions of the population. In calculating the specific indicators statistical and mathematical methods are used. The criteria indicator, attractiveness threshold, divides the rating of the Russian cities attractiveness into two parts: more attractive and less attractive cities.

The indicators necessary for an objective comparison of the cities in assessing their attractiveness can be derived based on the statistics. For the considered rating the threshold attractiveness index of the cities is equal to 13.15. All cities with the general attractiveness index higher than 13.15 are the most attractive Russian cities to the population and investors. These cities are ranked from 1 to 85 inclusive in the list. The leader of the list is Moscow with ratio 43.2. The list stops at Bryansk with a value of 13.2. Such cities as Murmansk, Veliky Novgorod, Kolomna, and Volzhsky are on the threshold of attractiveness with an index of 13.1. There are 79 Russian cities under the threshold of attractiveness. Novoshakhtinsk closes the list with a minimum value of the general index of 
attractiveness equal to 7.9 , which is facilitated by its extremely difficult economic and social situation.

The sense of the attractiveness threshold calculation is to determine the group of cities in the General rating of Russian cities attractiveness with a value higher than 13.15 with the likelihood of success in the fight for new investments and the flow of high-quality migration is significantly greater than in those cities that are below this threshold. This does not mean that the cities under the threshold of attractiveness will not receive new investments in their economy. However, it is possible to say with confidence that when analyzing the situation, investors and natural persons prefer for themselves the cities from the top of the list, with respect to the threshold of attractiveness. This can also be interpreted as follows: cities in the list ranked from 86 to 164 place will have to make greater efforts in order to attract in their economy new investments and migration flows than cities ranked from 1 to 85 place.

The basic rule set out by the Russian Union of Engineers is that the concept of attractiveness is complex and includes dozens of important components. The Russian Union of Engineers studied in detail the cites attractiveness to the populations, which provided an opportunity to analyze the current situation and take informed managerial decisions [14].

The quality of the urban living environment consists of several factors, each of which can be assessed with a certain set of indicators. Eleven factors of the urban living environment quality were selected for this rating:

1. population momentum is the main indicator of the population preferences to move within the territory of Russia, which considers only the actual changes in the total population of the city;

2. medical and demographic factor, an indicator of the level of medical and demographic conditions of the urban population, taking into account gender and age structure of the population, vital dynamic and migration, as well as morbidity indicators and life expectancy;

3. social characteristics of society, an indicator of stability of the population, combining employment and unemployment indicators, as well as the crime level;

4. wellbeing of citizens, the ratio of wage level to the minimum subsistence level in the region, demonstrates how people can satisfy their demands at the current wage rate;

5. social infrastructure of cities, an aggregate of industries and enterprises, providing social, welfare and recreation activities of the population, and evaluating changes in the quality of work and availability of educational institutions (pre-school and secondary educational institutions), health care (the bed capacity, availability of doctors, in-patient and out-patient medical facilities capacity), as well as cultural and sports institutions;

6. city's economy, volume of shipped goods and services, investment volume, revenues of public catering and trade enterprises, determining the development and attractiveness of the city's economy for business;

7. housing sector development: determined by comparing cities in terms of the overall housing per capita, new housing supply, as well as the share of shabby and hazardous dwelling in the overall volume of housing stock. This factor shows the living conditions of the population;

8. purchase affordability and housing maintenance allows to determine the wage share for the housing and utility sector service payment, as well as how many years it will take to acquire home at the current income level and average cost of square meter of living space, by calculating the share of costs for the housing and utility sector service from wage level, as well as the calculation of the required number of years to buy a house at the current income level and average cost of square meter of living space; this factor 
allows to evaluate the opportunity to improve the living conditions of local residents at their own expense;

9. transport infrastructure of the city estimates the density of the inner-city transport network, external and internal transport infrastructure level, allows to determine the ability of the existing transport system to cope with the passenger traffic;

10. engineering infrastructure of the city shows the availability of necessary utilities, allows to evaluate the condition of gas, heat, water supply and sewerage networks of the city;

11. stimulation of innovative activity reflects the share of enterprises engaged in innovative activities and changes in the number of granted patents, allows to estimate at what pace the region introduces innovations in production [15].

According to the findings from the survey, the most significant factors of the quality of urban living environment:

- Factor of housing sector development $-16.7 \%$,

- Factor of social infrastructure - $13.6 \%$,

- Factor of engineering infrastructure $-9.1 \%$,

- Factor of transport infrastructure $-9.1 \%$.

This arrangement of estimates and availability of statistical data generated on the basis of the considered methodological approach makes it an effective instrument for the development of managerial decisions related to the increase of the urban living environment attractiveness.

\section{Discussion}

The research task is implemented by the sequential execution of the statistical analysis stages using the discriminant analysis methods.

The selection of relevant indicators was carried out in the first stage. They include: indices of housing sector, social, engineering and transport infrastructure development, which characterize attractiveness of the city for living. Next task was to investigate the dependence of housing infrastructure development on the transport, social and engineering infrastructure creation factors determining its comfort for the residents.

The indices of housing, social, transport and engineering infrastructure development indicated in the "General rating of the attractiveness of urban living environment (habitat) according to the results of the cities activity in 2013 " were used as data for analysis. The studies were conducted using STATISTIKA program.

At the second stage of the study categorized histograms were built showing that variables in general have normal distribution for each group. Normal distribution of variables is necessary for the correct application of the discriminant analysis method.

At the third stage scatter diagrams were built to examine the relationship between selected features.

There are significant coefficients of correlation between the indicators of housing and social infrastructure development, as well as housing and transport infrastructure. The correlation coefficient for social infrastructure has a negative direction indicating the lag in the health care and educational facilities construction. Engineering infrastructure development indices slightly correlate with the housing infrastructure development, indicating a lack of complexity in the development of public utilities.

Evaluation of performance of mayors and heads of administrations of the largest Russian cities is conducted on the basis of analysis of combination of factors that affect the quality of urban living environment. These indicators summarize the main aspects of socioeconomic and economic component of the functioning of cities. These figures reflect the performance of previous and current heads of cities administrations.

The economic specificity of urban infrastructure is determined by: 
1. large-scale positive externalities, i.e, the operating results of the enterprises, which are not implemented in their profits, but in lowering costs and increased revenue of enterprises-consumers and growth of well-being of the population;

2. specialization in production of "public goods", i.e, products and services that cannot be paid separately by each consumer;

3. reduction (rather than growth, as in other industries) of marginal costs with increase in production $[16,17]$.

In view of the foregoing, in order to improve the efficiency of mayors and heads of administrations of Russian cities, it is necessary to create the urban development programs based on the results of the threshold attractiveness determination. These methodological approaches can be used for the development and substantiation of priorities of housing, social, transport and engineering infrastructure development.

\section{Conclusion}

The main purpose of urban development is to ensure the attractiveness of the urban living environment on the basis of comfort and safety. The creation of these conditions is associated with the comprehensive development of all components of the modern urban infrastructure, including housing, transport, social and engineering infrastructure.

The organization of management processes through the arrangement of conditions, adoption and implementation of appropriate managerial decisions is an important factor in their assessment.

The assessment of mayors and heads of administrations performance should be built on the available and practicable methods of calculation based on statistic data and knowledge of specific situations in the assessed cities. At that, the outcome indicators should reflect qualitatively and quantitatively the performance results of previous and current heads of municipal administrations.

The last decade, in the Russian economy the search of alternative to the direct government regulation of economic processes becomes actual. The Institute of publicprivate partnerships comes up with one of such alternatives in order to mobilize additional resources in the economy, reallocate risks, as well as redirect the efforts of private entrepreneurs structures towards the most significant for the society socio-economic problems, while maintaining at the state its inherent powers and functions.

\section{References}

1. T.K. Narezhny, E.M. Stein, Economy and Entrepreneurship 11-2, 204-209 (2014)

2. An.B. Mottaeva, As.B. Mottaeva, Int. Journal of Applied Engineering Research 9 (11), 6808-6816 (2016)

3. An.B. Mottaeva, MATEC Web of Conferences 73, 07020 (2016)

4. T. Blinova, MATEC Web of Conferences 73, 07023 (2016)

5. I. Karakozova, Y. Prokhorova, MATEC Web of Conferences 73, 07015 (2016)

6. As.B. Mottaeva, A. Zheltenkov, I. Stukanova, S. Ryabichenko, S. Zhuk, MATEC ,73 , 07026 (2016)

7. K. Kulakov, M. Rakovskaya, Theory of property, 90-96 (2015)

8. I. Karakozova, MATEC , 73, 07014 (2016)

9. N. Verstina, MATEC , 73, 07022 (2016)

10. O. Samson, The space economy 1-2, 162-166 (2009) 
11. G. Potasheva, MATEC Web of Conferences 73, 07004 (2016)

12. V.Y. Lubovnia, I.F. Zaitsev, A.K. Ushakov, O.S. Pchelintcev, Economics 5, 9 (2013)

13. V. Gerasimova, Procedia Engineering 165, 1395 - 1401 (2016)

14. Strategy for the development of housing and communal services in the Russian Federation for the period until 2020 (80-r, Moscow, 2016)

15. R. Yanbykh, Russian economic developments 5, 46-49 (2013)

16. Regions of Russia. Socio-economic indicators, http://www.gks.ru (2013)

17. Federal State Statistics Service (Rosstat), http://www.gks.ru 